\title{
Successfully Treatment of Proteus Mirabilis - Associated Meningitis in a Neonate by Carbapenem - Case Report and Review
}

\author{
Suzan Nasser ${ }^{1}$, Moran Avni ${ }^{3}$, Boshra N¹, Jerdev Michael ${ }^{2}$, AZ Seed ${ }^{3}$, Bayan H¹, Ehsan N¹, Haia N¹ and Wael Nasser ${ }^{1,3 *}$ \\ ${ }^{1}$ Nephrology \& Hypertension Division, Faculty of Medicine in Galillee, Baruch-Padeh Poriya Medical Center, Azrieli University, Lower Galilee, Israel \\ ${ }^{2}$ Department of Radiology, Baruch Padeh Poriya Medical Center, Lower Galilee, Israel
}

${ }^{3}$ Department of Pediatrics, Baruch Padeh Poriya Medical Center, Lower Galilee, Israel

\begin{abstract}
Proteus mirabilis is a Gram-negative, facultatively anaerobic, rod-shaped bacterium. Proteus mirabilis is most frequently associated with infections of the urinary tract, especially in complicated or catheter-associated urinary tract infections.

Although $P$. mirabilis is not commonly implicated as a causative organism in neonatal meningitis, its recognition is so important because the disease progresses rapidly and has poor prognosis. We present a case of a 14-day-old full term male infant that was admitted to our Emergency Department due to fever up to 39.6, with no vomiting, cough or diarrhea. According to the parents the infant underwent a circumcision 6 days before the fever started, in addition at home a father and sister had flue like symptoms. Sepsis workup was done and antibiotics was started include cefotaxime, amoxcilin, gentamycin. On the second day of admission, the CSF culture revealed a growth of $P$. mirabilis. No growth was reported from urine and blood cultures.

Based on the possibility of $A m p C \beta$ lactamase production that may be induced by the Cefotaxime, the antibiotic therapy was changed to IV meropenem $120 \mathrm{mg} / \mathrm{kg} /$ day divided q8h that was given for 3 weeks. Under this treatment, the baby was getting better with normal vital signs, and repeated normal physical examination including neurological examination. Several repeated brain US scans were also normal. Repeated CSF examination after 72 hours of treatment with meropenem revealed sterile fluid. At discharge, the patient had normal physical, and specifically neurological, and ophthalmological examinations, as well as normal brain US.
\end{abstract}

Keywords: Proteus mirabilis; Meningitis; Neonate; Meropenem

\section{Introduction}

In neonates, the Gram-negative bacteria is most frequently the pathogen of the urinary tract such as Ecoli, Proteus, Klebsella and gram positive enterococcus.

P. mirbilis a pathogen that belongs to a group of bacteria that carry a chromosomally encoded gene for AmpC- and inducible extended-spectrum $\beta$ lactamase. This gene may be induced to produce the enzyme by exposure to beta-lactam agents, mostly $3^{\text {rd }}$ generation cephalosporins [1].

On the other hand Carbapenem agents (such as imipenem or meropenem) have excellent penetration to the brain tissue, extensive coverage to all frequent CNS pathogens in neonates, and specifically a superiority on $3^{\text {rd }}$ generation cephalosporin in bacteria carrying AmpC [2].

About $4 \%$ of neonatal sepsis events caused by P. mirabilis; however, there have been only a few reports of meningitis in neonates associated with this bacterium [3-6].

Few cases of neonatal $P$. mirabilis meningitis have been reported in the literature. Most patients exhibited lethargy, poor feeding, and fever within days after birth as the initial symptoms, and rapid progression resulting in severe neurological symptoms or death. In addition to initial studies to identify neonatal sepsis or meningitis brain imaging studies are important because progression of this disease can occur even after normalization of cerebrospinal fluid (CSF) findings through the use of antibiotics.

Although all neonates were treated with various broad-spectrum agents, including $3^{\text {rd }}$ generation Cephalosporins, outcomes were poor. We report a case of a neonate who suffered from Proteus mirabilisassociated meningitis, who was successfully treated with Meropenem.
There have been numerous reports of production of extendedspectrum beta-lactamases (ESBLs) by Proteus spp. The ESBLs can confer resistance to $3^{\text {rd }}$ generation cephalosporins such as cefotaxime, ceftriaxone and ceftazidime, as well as the monobactam, aztreonam. The cephamycins (cefoxitin, cefotetan and cefmetazole) and the carbapenems (imipenem and meropenem) are generally not hydrolyzed by ESBLs.

Carbapenems are generally active against $P$. mirabilis. However, imipenem MICs are frequently higher for $P$. mirabilis compared to other members of the Enterobacteriaceae, Meropenem is more potent than imipenem against $P$. mirabilis.

\section{Case Report}

A 14-day-old full-term male infant was admitted to our Emergency Department due to fever. His medical history was only remarkable for circumcision five days before the admission. On admission his fever was $39.6^{\circ} \mathrm{C}$, but the rest of the physical examination was unremarkable.

A full sepsis investigation was done. Blood tests revealed leukocyte count of $18,500 / \mathrm{mm}^{3}$ of which $60 \%$ were neutrophils, hemoglobin

*Corresponding author: Wael Nasser, Department of Pediatric Nephrology, Baruch Padeh Poriya Medical Center, Lower Galilee, Israel, Tel: +972506267756; E-mail: wael-nasser@hotmail.com

Received: December 11, 2019; Accepted: December 20, 2019; Published: December 24, 2019

Citation: Nasser S, Avni M, Boshra N, Michael J, Seed AZ, et al. (2019) Successfully Treatment of Proteus Mirabilis - Associated Meningitis in a Neonate by Carbapenem - Case Report and Review. J Nephrol Ther 9: 342.

Copyright: ( $) 2019$ Nasser S, et al. This is an open-access article distributed unde the terms of the Creative Commons Attribution License, which permits unrestricted use, distribution, and reproduction in any medium, provided the original author and source are credited. 
Citation: Nasser S, Avni M, Boshra N, Michael J, Seed AZ, et al. (2019) Successfully Treatment of Proteus Mirabilis - Associated Meningitis in a Neonate by Carbapenem - Case Report and Review. J Nephrol Ther 9: 342.

Page 2 of 3

and platelet levels are normal and normal blood CRP and electrolyte levels. Cerebrospinal fluid (CSF) examination revealed normal levels of protein and glucose, 320 leukocytes $/ \mathrm{mm}^{3}$, of which $74 \%$ were neutrophils, and Gram stain that was negative for bacteria.

Therapy with IV Cefotaxime $200 \mathrm{mg} / \mathrm{kg} /$ day divided $\mathrm{q} 6 \mathrm{~h}$, IV gentamicin $5 \mathrm{mg} / \mathrm{kg}$ q24h, and IV Ampicillin $200 \mathrm{mg} / \mathrm{kg} /$ day divided q8h was started.

On the second day of admission, the CSF culture revealed a growth of $P$. mirabilis that was sensitive to amikacin, ceftazidime, ceftriaxone, cefuroxime-sodium, chloramphenicol, ciprofloxacin, meropenem, gentamicin, piperacillin/tazobactam, and trimethoprim/ sulfamethoxazole. No growth was reported from urine and blood cultures.

Based on the possibility of AmpC $\beta$ lactamase production that may be induced by the Cefotaxime, the antibiotic therapy was changed to IV meropenem $120 \mathrm{mg} / \mathrm{kg} /$ day divided q $8 \mathrm{~h}$ that was given for 3 weeks. Under this treatment, the baby was well with normal vital signs, and repeated normal physical including neurological examination. Several repeated brain US scans were also normal. Repeated CSF examination after 72 hours of treatment with meropenem revealed sterile fluid. At discharge, the patient had normal physical, and specifically neurological, and ophthalmological examinations, as well as normal brain US (Figure 1)

\section{Discussion}

Proteus mirabilis-associated meningitis had a complete recovery with no sequela following treatment with meropenem. The proximity to the circumcision suggests that the source for his infection was the penetration of the bacteria via the wound to the bloodstream and the nervous system.

The literature search for similar reports between the years 1980 and 2019 revealed only a few cases of neonatal P. mirabilis meningitis (Table 1). All cases had been treated by beta lactam agents as part of the therapeutic regimens, all the cases that was treated with Cefotaxime had a very complicated hospitalization, in a few cases brain abscesses were detected, and suffered from severe neurological sequela (Figure 2). The only case who remains with no sequela was treated with meropenem.

Changing therapy to meropenem when Proteus mirabilis was detected as the causative agent was decided because of the possibility of AmpC gene induction by Cefotaxime, leading to production of resistance ESBL of the bacteria that might have happened in the previous cases.

\section{Conclusion}

Proteus mirabilis-associated neonatal meningitis is very rare but may be associated with very poor prognosis if not appropriately treated. Therapy with carbapenem should be given to all patients suffering with this infection in order to prevent production of the inducible ESBL.
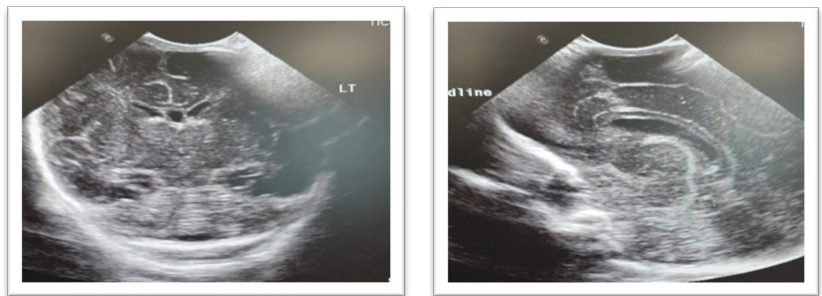

Figure 1: Brain US showing normal ventricles without hydrocephalus or abscess.

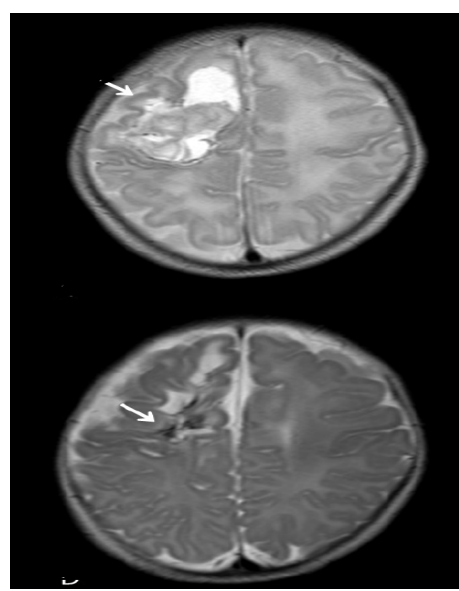

Figure 2: MRI of the brain with frontal lobe abscesses.

\begin{tabular}{|c|c|c|c|c|c|c|c|}
\hline $\begin{array}{c}\text { Reference } \\
\text { No. }\end{array}$ & Age(days) & Sex & $\begin{array}{l}\text { Presenting } \\
\text { signs }\end{array}$ & CSF Finding & Antibiotic treatment & $\begin{array}{l}\text { Image finding } \\
\text { during admission }\end{array}$ & Prognosis \\
\hline 3 & 1 & Female & $\begin{array}{l}\text { Shock symptoms: } \\
\text { fever, tachypnea, } \\
\text { jaundice }\end{array}$ & $\begin{array}{c}\text { First sample: Pleocytosis } \\
\text { with no bacterial growth. } \\
\text { Second sample after } \\
\text { deterioration: growth of } P \text {. } \\
\text { mirabilis }\end{array}$ & $\begin{array}{c}\text { Gentamicin, Penicillin, and } \\
\text { Chloramphenicol, which later was } \\
\text { changed to co-trimoxazole and } \\
\text { gentamicin }\end{array}$ & $\begin{array}{l}\text { Bilateral frontal } \\
\text { abscess }\end{array}$ & $\begin{array}{l}\text { Death } 2 \text { months } \\
\text { old. }\end{array}$ \\
\hline 3 & 37 & Male & $\begin{array}{l}\text { Convulsion and } \\
\text { increased head } \\
\text { circumference }\end{array}$ & $\begin{array}{l}\text { *Subdural aspiration yielded } \\
200 \text { mil of pus, and culture } \\
\text { was positive for } P \text {. mirabilis }\end{array}$ & $\begin{array}{l}\text { Gentamycin, Ampicillin and co- } \\
\text { trimoxazole. }\end{array}$ & $\begin{array}{l}\text { Frontal abscess and } \\
\text { large hydrocephalus. }\end{array}$ & $\begin{array}{l}\text { Poor - severe } \\
\text { mental disability }\end{array}$ \\
\hline 4 & 5 & Female & $\begin{array}{l}\text { Seizures, } \\
\text { opisthotonus } \\
\text { posture and } \\
\text { jaundice }\end{array}$ & $\begin{array}{l}\text { Blood and CSF cultures } \\
\text { were positive for } P \text {. mirabilis } \\
\text { growth }\end{array}$ & Aminoglycoside and Cefotaxime & $\begin{array}{l}\text { Large abscess at the } \\
\text { right frontal lobe and } \\
\text { meningio-ventriculitis }\end{array}$ & $\begin{array}{l}\text { Death } 15 \text { days } \\
\text { old. }\end{array}$ \\
\hline 5 & 6 & Male & $\begin{array}{l}\text { Severe jaundice, } \\
\text { poor feeding and } \\
\text { lethargy }\end{array}$ & $\begin{array}{l}\text { CSF: Pleocytosis, low } \\
\text { glucose level of } 7 \mathrm{mg} / \mathrm{dL} \text {. } \\
\text { Culture was positive for } P \text {. } \\
\text { mirabilis growth }\end{array}$ & Ampicillin and Cefotaxime & $\begin{array}{l}\text { CT scan showed } \\
\text { significant anoxic } \\
\text { brain injury }\end{array}$ & Death 8 days old \\
\hline Current Case & 14 & Male & Fever & $\begin{array}{l}\text { CSF culture was positive for } \\
\text { P. mirabilis growth }\end{array}$ & $\begin{array}{l}\text { Initiated with Ampicillin, Gentamycin, } \\
\text { and Cefotaxime, which was later } \\
\text { changed to Meropenem }\end{array}$ & Normal & $\begin{array}{c}\text { Good, released } \\
\text { home after } 21 \\
\text { days of treatment. }\end{array}$ \\
\hline
\end{tabular}

Table 1: Case review of $P$. mirabilis meningitis 
Citation: Nasser S, Avni M, Boshra N, Michael J, Seed AZ, et al. (2019) Successfully Treatment of Proteus Mirabilis - Associated Meningitis in a Neonate by Carbapenem - Case Report and Review. J Nephrol Ther 9: 342.

Page 3 of 3

We conclude that in our case the good outcome for the patient was due to the fast and prolonged treatment with meropenem. More research is needed to prove the benefit of meropenem, especially due to rare and unknown number of Proteus mirabilis neonatal meningitis cases.

\section{References}

1. Choi SH, Lee JE, Park SJ, Choi SH, Lee SO, et al. (2008) Emergence of antibiotic resistance during therapy for infections caused by enterbacteriaceae producing AmpC beta-lactamase: Implications for antibiotic use. Antimicrob Agents Chemother 52: 995-1000.

2. Straussberg R, Harel L, Amir J (2001) Long-Term outcome of neonatal
Citrobacter koseri (diversus) meningitis treated with imipenem/meropenem and surgical drainage. Infection 29: 280-282.

3. Smith ML, Mellor D (1980) Proteus mirabilis meningitis and cerebral abscess in the newborn period. Arch Dis Child 55: 308-310.

4. Juyal D, Rathaur VK, Sharma N (2013) Neonatal meningoventriculitis due to Proteus Mirabilis - A Case Report. J Clin Diagn Res 7: 369-370.

5. Phan H, Lehman D (2012) Cerebral abscess complicating Proteus mirabilis meningitis in a newborn infant. J Child Neurol 27: 405-407.

6. Chung MH, Kim G, Han A, Lee J (2017) Case report of neonatal proteus mirabilis meningitis and brain abscess with negative initial image finding. Consideration of serial imaging studies. Neonatal Med 24: 187-191. 